\title{
India's on-grid solar power development: Historical transitions, present status and future driving forces
}

\author{
Enayat A. Moallemi ${ }^{\mathrm{a}}$, Lu Aye ${ }^{\mathrm{a}, *}$, John M. Webb ${ }^{\mathrm{b}}$, Fjalar J. de Haan $^{\mathrm{a}, \mathrm{c}}$, Biju A. George ${ }^{\mathrm{a}, \mathrm{d}}$ \\ a Renewable Energy and Energy Efficiency Group, Department of Infrastructure Engineering, The University of Melbourne, Victoria 3010, Australia \\ b Centre for Transformative Innovation, Faculty of Business and Law, Swinburne University of Technology, Victoria 3010, Australia \\ ${ }^{\mathrm{c}}$ Melbourne Sustainable Society Institute, Melbourne School of Design, The University of Melbourne, Victoria 3010, Australia \\ d Integrated Water and Land Management Program, International Centre for Agricultural Research in the Dry Areas, Cairo, Egypt
}

\section{A R T I C L E I N F O}

\section{Keywords:}

On-grid solar electricity

Sustainability transitions

Renewable electricity

India

\begin{abstract}
A B S T R A C T
India with a fast growing demand for electricity and increasing consideration to emissions reduction is investing strongly in renewable electricity generation. Among renewables, the Central and State Governments have set aspirational targets for on-grid solar electricity and legislated several supporting policies to realise these targets. As a result of the favourable political environment, the development of on-grid solar, in terms of the rate of growth in installed capacity, has been increasing in the recent years, and it is expected to continue in the future. This paper aims to investigate the impact of historical transitions of India's electricity sector on the ongoing development of on-grid solar electricity and to explore the prospect of solar sector development in the future. First of all, we investigate how the historical transformation of governmental intervention's approach intertwined with the gradual shift of the source of generation has paved the way for the current achievements in on-grid solar electricity. Second, we envision the future challenges and opportunities for the development of solar sector by looking ahead and discussing the continuity of government's support and the prospective competitions between different sources. We conclude the paper with some required steps to be taken in order to secure the achievement of the targets in solar electricity in the future.
\end{abstract}

\section{Introduction}

India as the second most populous country is currently experiencing a steep economic growth and subsequently, a rapidly growing energy demand. In 2012, the country was ranked as the third and fifth highest country in global energy and electricity consumption respectively [1]. Urbanisation, economic development of society, the expansion of industry and the development of new services have contributed to a sharp increase in electricity demand. The demand is expected to rise even further in the near future (see Figs. 1 and 2). To cover this growing demand, $20 \mathrm{GW}$ of new generation capacity will be required annually by 2020 [2]. The (on-grid) installed capacity from different sources has been increased appreciably in the past couple of years. Despite the high level of electricity generation, the country still suffers from about $10 \%$ generation deficit of total electricity demand, which puts almost 300 million people with no access to electricity [3,4].
The country's required electricity is generated in different methods: on-grid which is the main method for urban areas as well as widely used for agriculture and industry, off-grid which is more common for rural areas and captive power plants which are mostly used for industries. Electricity is also being generated from different conventional and unconventional sources. In 2014, from the total installed capacity of $255 \mathrm{GW}$ [6], the share of conventional sources is about $70 \%$, where coal alone accounts for about $84 \%$ of it. Large hydroelectric and renewables take the second and third rank of the largest installed capacity respectively (see Table 1).

The importance of renewable energy in developing countries and, more specifically, in India's electricity sector, has become significantly higher in recent years (see Table 2). On-grid renewables are seen as a new way to address the concerns about the gap between demand and supply, energy security, energy equity with safe and convenient access and the global commitment to emissions reduction [7-9]. In spite of

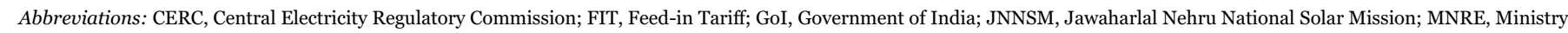

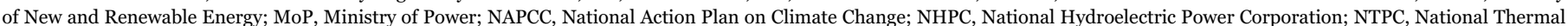

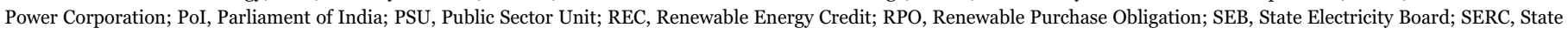
Electricity Regulatory Commission; SOE, State-Owned Enterprise; TP, National Tariff Policy 2006

* Corresponding author.

E-mail address: lua@unimelb.edu.au (L. Aye).
} 


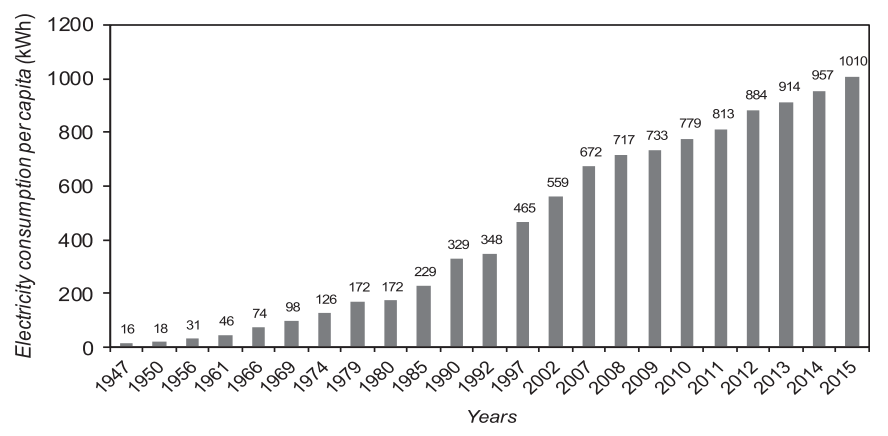

Fig. 1. Growth of electricity consumption per capita in India 1947-2015 [3].

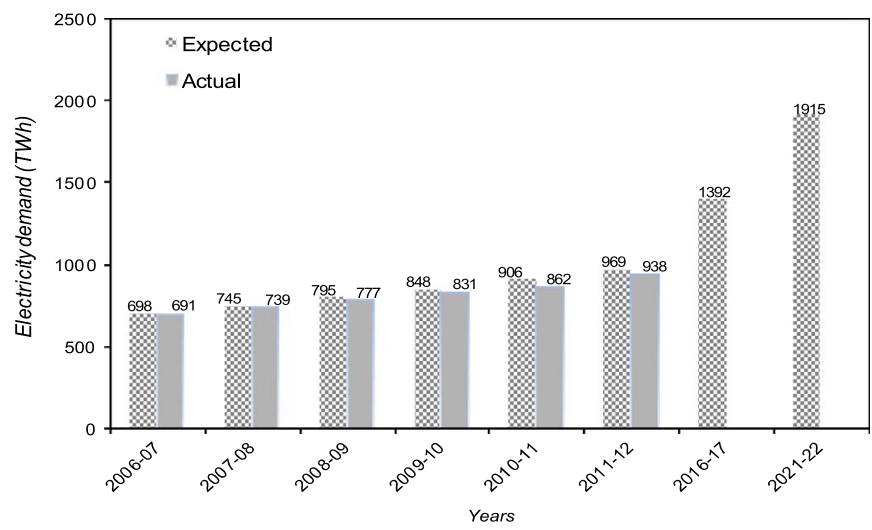

Fig. 2. The expected and actual electricity demand in India 2006-2022 [5].

Table 1

The share of different sources in India's on-grid installed capacity in 2014 [4].

\begin{tabular}{lll}
\hline Fuel source & Installed capacity (MW) & Share (\%) \\
\hline Coal & 153,571 & 60 \\
Gas & 22,971 & 9 \\
Oil & 1,200 & $<1$ \\
Hydro & 40,799 & 16 \\
Nuclear & 4,780 & 2 \\
Renewables & 31,692 & 12 \\
Total & 255,013 & 100 \\
\hline
\end{tabular}

Table 2

The growth of different on-grid renewable options in MW $[15,16]$.

\begin{tabular}{|c|c|c|c|c|c|c|}
\hline Renewable & 1992 & 2002 & 2007 & 2012 & 2014 & $\mathbf{2 0 1 5}^{\mathrm{a}}$ \\
\hline Wind power & 38 & 1667 & 7094 & 17352 & 20298 & 25188 \\
\hline Small hydro & 79 & 1438 & 1975 & 3395 & 3774 & 4188 \\
\hline Solar power & 0.6 & 1 & 2 & 941 & 2208 & 5248 \\
\hline $\begin{array}{l}\text { Biomass power and } \\
\text { cogeneration-bagasse }\end{array}$ & - & 390 & 1140 & 3135 & 3797 & 4761 \\
\hline $\begin{array}{l}\text { Waste to energy (urban and } \\
\text { industrial) }\end{array}$ & - & - & 43 & 89 & 99 & 127 \\
\hline Total & 118 & 3496 & 10253 & 24912 & 30176 & 39511 \\
\hline
\end{tabular}

${ }^{\text {a }}$ Up to January 2016.

small share for renewables ( $12 \%$ of total installed capacity), India is considered generally as a successful example among developing countries in renewable electricity in terms of the annual growth of investment and installed capacity [10-13]. This growth has not been uniform across different States. India has 29 States and 7 union territories with a shared social, economic, and political background. However, they have different behavioural patterns and priorities, disparate availability of potential renewable sources, flexible policies and regulations, built infrastructures and available networks. Across the country, eight States, including Tamil Nadu, Andhra Pradesh,
Karnataka, Gujarat, Maharashtra, Rajasthan, Himachal Pradesh, and Jammu \& Kashmir, account for $80-90 \%$ of existing total renewable capacity in the country. Among them, Rajasthan and Gujarat are top two States with the highest installed capacity for on-grid solar (PV), and Tamil Nadu and Gujarat are two top States for wind power [14].

In 2011, the growth of renewable investment was (about 62\%) higher compared to 2010. Most of this investment has come to wind ( $\$ 5.9$ billion) and solar ( $\$ 4.7$ billion) sectors as they have been the top priorities of the government [17]. Wind has the highest capacity of ongrid electricity, and solar has the highest annual rate of growth since 2012. Wind electricity is a closer option to grid parity which makes it more affordable compared to solar electricity. However, most of appropriate sites for wind farms have been exploited which may limit the rapid expansion of wind energy in future to some extent. On the other hand, solar electricity benefits from large potential solar radiation (annual average 19-22 $\mathrm{MJ} \mathrm{m}^{-2}$ per day [18]) and available lands which are mainly unexploited. The price of solar technology is also falling which makes it more competitive in the near future.

Considering the growing importance of solar electricity in India, this paper aims to review the development of India's on-grid solar electricity. Several previous researches have studied the development of the Indian renewable electricity sector in general, and solar electricity in particular, from different perspectives [19-22]. We differentiate our review from the previous studies by investigating the development of solar electricity as the continuation of historical transitions in the whole electricity sector. India's electricity sector has experienced at least two major transitions so far: the first is a transition from a State-owned sector to a State-influenced liberalised sector and the second is a transition from conventional to renewable sources of energy for electricity generation. These historical transitions with several institutional and structural changes have laid the ground for on-grid solar electricity development. The paper seeks to answer: how has the ongoing development of solar electricity been built upon the privatisation of electricity sector and the empowerment of renewable energy in the past? Moreover, it intends to discuss: how will the future look for on-grid solar electricity based on the prospect of its driving forces?

The main method used in this paper is the review of documents with a theoretical heuristic and supported by three groups of facts: raw facts, stylised facts and inferred facts.

1. 'Raw facts' are the data collected from the review of the documents. They are the numbers or exact qualitative statements (which are cited to their references). The documents are scholarly articles and reports that have been published in academia, international energy organisations [11,23-25] and the Indian government bodies (e.g. Ministry of Power [26], Planning Commission [27], Central Electricity Authority [3], Government of India [28-30]). Some data required for this review (data associated with the very recent developments) are collected during the $1^{\text {st }}$ Re-Invest Summit, which was held in New Delhi, February 2015. ${ }^{1}$

2. The collected data are categorised and structured in a stylised manner with a theoretical heuristic in sustainability transitions field $[31,32]$. The theory is not explained here as it is out of the scope of the review paper and has been discussed before [33,34]. It generates 'stylised facts'. They are qualitative storylines (instead of rigid raw data) for a better interpretation of data to readers.

3 . And at the end, the inferences about the prospect of solar sector and its challenges are made by looking over the whole storyline as well as by using the recent discussion in the $1^{\text {st }}$ Re-Invest Summit around the future of the Indian electricity sector. They are 'inferred facts'.

The rest of the paper is structured as follows. In Sections 2 and 3,

\footnotetext{
${ }^{1}$ http://www.re-invest.in/
} 
two major historical transitions are presented and their influences on the development of solar electricity are discussed. Section 4 takes a closer look at the rise of on-grid solar electricity and elaborates the recent experience from the first national policy document for solar energy resource in India. Section 5 envisions the future for the Indian solar sector based on the past and the present state of solar power. Finally, the concluding remarks of the study are presented in Section 6.

\section{Transition in the governmental interventions: from a purely nationalistic to a partially liberalised approach}

The development of India's renewable electricity does happen neither in a pure liberal market economy (like the U.S.) nor in a government-controlled state capitalism (like China) [35]. It should be explained in a specific condition or as we call it in a State-influenced niche empowerment [34]. In this condition, solar electricity is empowered from inside and by the interactions of self-interested private sector's actors who decide to invest on renewable options based a costbenefit analysis. About $77 \%$ of total $31 \mathrm{GW}$ of installed renewables (in 2014) are run by private entities $[3,14]$. They operate in a semi-market economic condition and are also influenced by command-and-control and market-based policies of the Central and State Governments $[36,37]$. However, the way that electricity market is currently working is different from how it worked before. The partially liberalised approach is the result of long-term transition from a government monopoly in 1950s towards the privatisation of the electricity sector in 1990s. Based on the discussion on the political economy of the Indian electricity sector's reform by Victor, Heller [38], this structural transition can be divided into three main phases as follows.

\subsection{Phase 1: towards State-owned enterprises, a socialistic view (1950s-1960s)}

The growth of India's electricity sector can be traced back to postindependence time in 1947, when the Government of India enacted the 1948 Electricity Act [39]. Taking a socialistic stand, Jawaharlal Nehru's Government made both the Central and State Governments constitutionally responsible for power sector (the concurrent list of the Constitution $^{2}$ ) in the 1948 Electricity Act. Accordingly, the government formed State-Owned Enterprises (SOEs) involving in the development and operation of power sector and also established State Electricity Boards (SEBs) responsible for regulating generation, transmission and distribution of electricity. SOEs, due to their governmental ownership, were not working efficiently. They were being continuously fed by different support schemes in form of grants and subsidies. Because of the SOEs' lack of performance, States were facing widespread blackouts during 1970s [38]. The governmental ownership had another symptom, and that was the high dependency of SEBs on the State Governments' funding and subsequently, the highly politicised decisions of SEBs in setting tariffs for different users.

\subsection{Phase 2: towards centralisation, a nationalistic view (1970s- 1980s)}

The Central Government responded to the problems caused by the high dependency to States by increasing the central control on the electricity sector. This was coincident with Prime Minister (PM) Indira Gandhi's nationalistic policies in different sectors. This period led to the establishment of some public-owned generation and transmission companies, such as National Hydroelectric Power Corporation (NHPC) for building large hydro projects and then National Thermal Power

\footnotetext{
${ }^{2}$ Concurrent list is 47 items which the both Central and State Governments are supposed to act together about.
}

Corporation (NTPC) ${ }^{3}$ for generating electricity from coal in $1975 .{ }^{4}$ At this time and till 1980s, the country was experiencing a moderate economic growth of about $5 \%$ more than the population growth which was mainly due to government expenditure and external debt [1]. This growth demanded more investments in electricity generation, transmission and distribution. The increase in the government expenditure was at the same time with the 1970s' oil price shocks and large subsidies to agricultural irrigation for securing food supply, which both put additional burdens on the government [38].

\subsection{Phase 3: towards privatisation, a reformist view (1990s- present)}

The government expenditures and external debt left the country in a severe financial crisis in 1991 with having foreign exchange reserves to just a few of days of import $[40,41]$. SEBs were also the largest drain for the States' budget, making the State Governments unable to continue their support in late 1980s. This situation was approximately at the same time as the strong economic growth in China with the interaction of institutions and market forces as its main driver.

The big deficit in budget in early 1990s made the reformist Central Government to conduct reforms in the country's economic system. Power sector in particular was suffering from a financial crisis and the inability to provide the required infrastructures. The structural reform in power sector was aimed to raise some financial resources and to immediately target the existing shortage in power capacity [42]. The government carried out a major institutional change (i.e. 1991 amendment in 1948 Electricity Act) and encouraged disinvestment, private sector investment and foreign investment to boost Independent Power Plants (IPPs) [43]. The involvement of private sector was allowed with a specific tariff and the $16 \%$ guaranteed rate of return. From mid 1990s, the State-level restructuring of SEBs into generation, transmission and distribution (i.e. functional unbundling) and selling them to independent (private or regulatory) actors were also started. The unbundling process was facing resistances from labour unions who were opposing governmental job cuts and also from farmers who were opposing an increase in price of cheap electricity [38]. At the end, the outcome of this period was the establishment of independent regulatory commissions (Central Electricity Regulatory Commission (CERC) and State Electricity Regulatory Commissions (SERCs)) for setting electricity tariff for consumers without the direct influence of the State Governments.

While the reform was satisfactory at the beginning, it did not end up successfully in 1990s. Many letters of intent from private sector were submitted, but no significant actual investments were made, and NTPC remained the main supplier during 1990s [38]. Moreover, due to the guaranteed and high rate of return, the mentality of "power at any cost" was encouraged which left the government alone with some expensive projects. It was in early 2000s that the involvement of private sector started to become significant following the enactment of the Electricity Act 2003 by the Central Government [30].

\section{Transition in the source of electricity generation: from conventional to renewables}

Much of the growth of electricity sector can be attributed to postindependence period. It can be mostly described as a competition between conventional systems (including coal, gas, oil, nuclear and hydro) and renewable systems (including wind, bioenergy and solar). The transition from conventional to renewables can be divided in three

\footnotetext{
${ }^{3}$ NTPC extended its mission to hydro power, power trading and consultancy, and having its own transmission lines and turned to a united national entity on power sector with $27 \%$ of total electricity generation in 1990 s.

${ }^{4}$ Although NTPC was partially (10.5\%) sold to investors and public institutions later in 2004.
} 
phases as follows [34].

\subsection{Phase 1: a capability building approach to renewables (1970s- 1990s)}

Till 1970s almost the whole electricity sector was supplied by conventional systems, including large hydro power and coal, and there was no presence of renewable electricity [44]. To give an overview, in 1974, the electricity demand was about 63 billion $\mathrm{kWh}$ which was being supplied by the total installed capacity of $16.7 \mathrm{GW}$, all owned by the Central and State Governments [1]. From this total capacity, 51\% was operated with coal, $2 \%$ with gas and diesel, $4 \%$ with nuclear, $42 \%$ with large hydro and $0 \%$ with renewables (i.e. wind and solar) [1]. However, the 1970s' oil price shock and awareness for energy security, along with the early 1990's financial crisis and the engagement of private sector in infrastructure development triggered a transformation towards renewable sources [42]. To facilitate this transformation, the government stepped in and devised supporting policies, such as $80 \%$ accelerated depreciation for wind projects to encourage manufacturing and installed capacity, as well as to create a competitive electricity market for private investments [15]. This was a 'capability building approach', a similar government's standpoint for the early-stage development of renewables in developing countries [45]. This phase was marked by a sharp increase in total installed capacity for renewables, mostly for wind. This phase, however, was not successful for generation due to the low capacity factors of the installed facilities $[46,47]$.

\subsection{Phase 2: a generation motivating approach for renewables (2000s-present)}

The growing concerns about energy supply and energy security aligned with the supporting policies made a change in the share of different electricity generation systems during Phase 1 . In 2002, from the $105 \mathrm{GW}$ total installed capacity, $71 \%$ was from conventional including coal, gas and diesel, $26 \%$ was from hydroelectric power, $3 \%$ was from nuclear power, $2 \%$ was from wind power and another $0.3 \%$ was from other renewables including on-grid solar and biomass $[3,4]$. However, during the subsequent years after Phase 1, some other concerns also mattered. They were the lack of satisfying exploitation from installed renewables and the rise of energy equity and energy convenience in the country. These concerns drove another wave of transformation, this time mainly with the support of generation-based incentives such as Feed-in Tariff (FIT) and Renewable Purchase Obligation (RPO) (Electricity Act 2003 [30] and National Tariff Policy 2006 [28]) [15]. The government also made explicit targets for grid-connectivity (e.g. $5 \%$ on-grid renewable by 2012 in $10^{\text {th }}$ and $11^{\text {th }}$ Five Year National Plans) in order to improve the convenient and the same quality access to electricity $[48,49]$.

\subsection{Phase 3: a solar-oriented approach (2008-present)}

The emphasis on generation-based policies and grid-connectivity intensified the reorientation of India's electricity sector towards renewables. In 2007, from the total installed capacity of $132.3 \mathrm{GW}$ (which was increased by $700 \%$ compared to the capacity in 1974), the share for coal, gas and oil was $65 \%$, for hydro power was $26 \%$, for wind power was $5 \%$, for on-grid solar power was $0.1 \%$, for other renewables (ongrid biomass) was $0.8 \%$ and for nuclear was $3 \%[3,27]$. Another major transformation took place in 2008 in order to deal with the escalating emissions as the side effect of the country's steep economic growth. This phase was started by the announcement of the National Action Plan on Climate Change (NAPCC) in 2008 [50] and Jawaharlal Nehru National Solar Mission (JNNSM) in 2010. They triggered the resurgence of on-grid solar in the electricity sector. The JNNSM targeted 20 GW installed capacity for on-grid PV and Concentrated Solar Power (CSP) by $2022[29,36]$. It also proposed generation-based policies for

Table 3

The description of policy instruments influencing the solar sector in India $[14,15,36,52,57]$.

Table 3a. Generation-based policy instruments

Renewable Purchase Obligation (RPO)

Renewable Energy Credits (REC)

Feed-in Tariff (FIT)

Table 3b. Financial policy instruments

Long-term power purchase contracts

Power Purchase Agreement (PPA)

Payment Security Mechanism

Time for financial closure
This market instrument mandates State and private distributors as well as captive power producers to purchase solar generated electricity. NAPCC mandated $5 \%$ of States electricity purchase from renewables in 2010, with 1\% increase per year until 2020 (15\% cumulative). The JNNSM also proposes RPO with $0.25 \%$ solar electricity of total purchase by 2013 and 3\% by 2022. It is a minimum level determined by the federal Government, and each State can have their own arrangement.

This scheme (with a specific quota for solar) was proposed in NAPCC by the MNRE and the Regulatory Commissions. Accordingly, $1 \mathrm{MWh}$ of renewable generated electricity is treated as a bundled good. In one part, it is sold as electricity and the other part as REC which can be traded between States. Solar electricity generators in States with high solar radiation (and if they do not have any tariff-based purchase agreement) can benefit from selling these certificates to distributors who need to meet their solar purchase obligations. While the price for REC is determined in the free market, it still needs to be controlled by upper-bound and lower-bound prices. The lower-bound and upper-bound are currently US $\$ 0.24 / \mathrm{kWh}$ and US $\$ 0.32 / \mathrm{kWh}$ determined by CERC. RECs are traded in two main exchanges, Indian Energy Exchange Limited in New Delhi and Power Exchange India Limited in Mumbai.

The responsibility to fix tariffs for purchase of renewable power lies with CERC and SERC. CERC sets the guidelines and norms for setting tariffs; however, States can remain flexible and announce their own version of tariffs. The minimum tariff determined by CERC is currently US $\$ 0.36 \mathrm{kWh}$ for solar photovoltaic. Government awards FIT contracts in a competitive process and with different mechanisms including firstcome first-served (FCFS), 'beauty contest' (Selecting projects based on predefined criteria) and reverse auction. When any FIT contract is awarded to a project, it will remain fixed for a period of 25 years. 
Table 3 (continued)

\begin{tabular}{|c|c|}
\hline \multirow{2}{*}{\multicolumn{2}{|c|}{ Table 3c. Capability building policy instruments }} \\
\hline & \\
\hline $\begin{array}{l}100 \% \text { foreign } \\
\text { investment }\end{array}$ & $\begin{array}{l}\text { With an aim to attract the required financial resources for } \\
\text { increasing solar generation capacities, } 100 \% \text { foreign } \\
\text { investment is permitted in equity. }\end{array}$ \\
\hline Tax holidays & $\begin{array}{l}\text { The developers can benefit from } 10 \text { years exemption from } \\
\text { corporate tax during the first } 15 \text { years of the project's life. }\end{array}$ \\
\hline $\begin{array}{l}\text { Concessional } \\
\text { custom and } \\
\text { excise duty }\end{array}$ & $\begin{array}{l}\text { This is the exemption of customs \& excise duty for on- } \\
\text { grid solar power projects in order to reduce the impact of } \\
\text { import duties and local manufacturing taxes on the cost of } \\
\text { major items used in solar power plants. }\end{array}$ \\
\hline $\begin{array}{l}\text { Site specific } \\
\quad \text { insolation data }\end{array}$ & $\begin{array}{l}\text { Making these data available assists financial institutes to } \\
\text { easily collect the required site specific insolation data for } \\
\text { investment assessments. This is the expansion of Solar } \\
\text { Radiation Resource Assessment (SRRA) which will help } \\
\text { developers to better justify the projects. }\end{array}$ \\
\hline $\begin{array}{l}\text { Viability Gap } \\
\text { Funding (VGF) }\end{array}$ & $\begin{array}{l}\text { VGF is a capital subsidy which provides a grant funding to } \\
\text { reduce the upfront capital costs of installed capacities. } \\
\text { MNRE proposes VGF in a reverse bidding process to } \\
\text { developers. }\end{array}$ \\
\hline
\end{tabular}

promoting on-grid solar generation such as RPO, REC, FIT, Long-term Power Purchase Contracts between distributors and developers, Power Sale Agreement with distributors, Payment Security Mechanism [51] (see Table 3). While some issues persisted in timely implementation of policies, the overall policy framework has been found generally influential in motivating private sector's participation and in boosting on-grid solar electricity [52]. The impact of this phase was that in 4 years after the JNSSM, the share of on-grid solar grew by 10 times ( $0.1 \%$ in 1010 to $1 \%$ in 2014 ). By 2014 , from the total installed capacity of $249.5 \mathrm{GW}$ [6], the share for conventional sources was $69 \%$, for hydro power was $18 \%$, for wind power was $8 \%$, for on-grid solar power was $1 \%$, other renewables was $2 \%$ and for nuclear was $2 \%[3,27]$.

\section{The resurgence of on-grid solar PV and Concentrating Solar Power (CSP)}

The potential national capacity of solar power is about $750 \mathrm{GW}$ [53], one of the highest in the world, but it had not been exploited until the JNNSM was officially launched in 2010. The JNNSM is a remarkable initiative in solar sector to secure a significant share for on-grid solar electricity in India's energy basket in future. It must be followed by all States, while they can have their own policy programs [54,55]. This is also a dynamic program, which is amended and updated as time passes and the results of previous steps are identified.

In response to this initiative, on-grid solar installed capacity has exponentially increased from $2 \mathrm{MW}$ in 2007 to $1000 \mathrm{MW}$ in 2012, to $2200 \mathrm{MW}$ in 2014, to $3000 \mathrm{MW}$ in early 2015 and to 5200 in early $2016[14,56]$. While the first triggers started during PM Singh's Government, the resurgence should be mainly attributed to PM Modi's Government which increased the JNNSM's target from $20 \mathrm{GW}$ to $100 \mathrm{GW}$ on-grid solar installed capacity by 2022 , comprising $40 \mathrm{GW}$ rooftops and $60 \mathrm{GW}$ solar power plants. This rapid increase of installed capacity aligned with the supporting political condition, especially in the government elected in 2014, can be seen as a trigger for the resurgence of solar electricity.

Several policies, ranging from generation-based to capability building policies, have been devised to achieve the solar targets. A summary of these policy instruments is provided in Table 3.

The JNNSM is being implemented in three phases [29]:

Phase I: The first phase was from 2010 to 2013 and targeted $1000 \mathrm{MW}$ (500 PV and $500 \mathrm{CSP}$ ) installed capacity for creating an initial market for solar power by bringing investors, EPC contractors and manufacturers together. The private sector role was significant in the installation of PVs during the first phase though they did not respond the same to CSP. This phase was commissioned in Batch I and Batch II with different tariffs auctioned in a reverse bidding process. The expensive generated solar power was bundled with coal power from NTPC in order to make it affordable for distributors. Phase I also mandated Domestic Content Requirement (DCR) to protect domestic manufacturing. According to this policy, developers had to buy locally manufactured PVs made by crystalline silicon technology, but it was not applied in thin film technology due to lack of enough experience/ manufacturers. This policy is argued among experts as being ineffective since it directed developers toward cheaper thin film imported from the US and China [14].

Phase II: The second phase started in 2013 and will continue till 2017, with an aim to facilitate a substantial increase in on-grid solar installed capacity. Some changes in national targets and policy initiatives have been made based on the preference of Modi's government and experiences from Phase I. In Phase II, more attention is given to solar PV (70\% of the target) as CSP was not supported by developers during the first phase. The State Governments also became responsible for $60 \%$ total installed capacity in Phase II. The MNRE has announced three draft schemes for the second phase. In Batch I, the scheme aims for $750 \mathrm{MW}$ on-grid solar with Viability Gap Funding (VGF) in a competitive reverse bidding process for project developers (no feed-in tariff). In addition to VGF which is as a capital subsidy, the Solar Energy Corporation of India (SECI) ${ }^{5}$ also guaranteed to buy the generated electricity from providers at a fixed rate and also to sell it to distributors for fixed rates over the long-term. For Batch II, the MNRE has proposed a State-specific bundling scheme for the development of $3000 \mathrm{MW}$ solar power projects, performed by NVVN. For Batch III, a State-specific VGF for development of 2000 MW solar power with PPA agreement for 25 years operated by SECI was proposed [14].

Phase III: The third phase will be from 2017 to 2022 which aims to reach a cumulative $100 \mathrm{GW}$ installed capacity and grid parity. The intended on-grid solar electricity includes large grid solar plants as well as grid-connected rooftop and small solar plants. No further details of the proposed policies to support the targets in Phase III have been revealed yet.

Several projects have been commissioned or planned in order to achieve the targets defined in the JNNSM. The MNRE has announced the goal to achieve a large share of the targets with Ultra Mega Solar Projects (UMSP) [14,58]. Charanka Solar Park in Gujarat is a commissioned UMSP with the capacity of $605 \mathrm{MW}$, and the MNRE has planned to install another 25 solar parks with 500 MW capacities each by 2020. The targets are also going to be satisfied at smaller scales. It is planned to support the installation of $40 \mathrm{GW}$ solar PV rooftops in the next five years. While the rate of generated electricity from solar rooftop is already economically viable, the government has provided subsidies (15\%) to make them more attractive for home owners and industrial and commercial users to invest. The MNRE also encourages solar PV plants between 1 and $10 \mathrm{MW}$ on canal tops. The Central Government has planned to build $100 \mathrm{MW}$ solar plants on canals by 2022 [29]. Currently, two of them have been commissioned, both in the State of Gujarat, one with $1 \mathrm{MW}$ on Sanand Canal and the other $10 \mathrm{MW}$ on Narmada Canal [14]. About $7000 \mathrm{MW}$ solar plant projects have also been planned by Public Sector Units (PSUs) such as the Indian Railways and Coal India Limited [59]. A 12 MW solar power project was installed at the international airport of Co Chi (State of Kerala) and it has become the first airport in the country fully operated by solar power.

\footnotetext{
${ }^{5} \mathrm{SECI}$ is a government-owned company which supervises the implementation of the JNNSM.
} 


\section{Discussion}

\subsection{The impact of historical transitions on the empowerment of on- grid solar electricity}

One question raised at the beginning of the paper was: how has the ongoing development of solar electricity been built upon the privatisation of electricity sector and the empowerment of renewable energy in the past? The review of the historical transitions in governmental intervention's approach and in the source of electricity generation can answer this question.

The historical transition towards a partially liberalised electricity sector laid the ground for the realisation of aspirational solar targets. The Government of India has targeted 100 GW solar electricity by 2022 which demands $\$ 100$ billion investment in solar sector [57]. While the government can invest an initial amount as an impetus towards achieving this target, a huge investment from private sector, foreign investors and Public Sector Units (PSUs) is still required to fully realise solar targets. The transition of governmental intervention's approach facilitated the inflow of the required investments. It allowed the involvement of the private sector and $100 \%$ foreign investment in solar projects. Unbundling of the electricity sector (reflected in the Electricity Act 2003), as another outcome of the transition, has also encouraged further private sector's participation. These institutional and structural changes have attracted a large number of private sector actors to India's renewable electricity; most of them to the generation side of the sector (see Fig. 3).

As the continuation of this historical transition, several sources of foreign investment were planned to support renewables including solar. They include US\$ 240 million (₹1600 Crore) loan from Japan International Co-operation Agency, US $\$ 1$ billion (₹6500 Crore) loan from US Ex-Im Bank and US\$ 110 million (₹700 Crore) from Agency Francaise de Developpement of France [59]. Many private investors have become interested to invest in solar electricity. They comprise private financial institutes such as Power Finance Corp (PFC), Indian Renewable Energy Development Agency (IREDA), ICICI Bank, Yes Bank, etc. In addition to private investors and foreign investment, PSUs, which used to be parts of conventional regime, are also investing in solar sector now. They can invest their surplus funds in solar electricity to use its depreciated/exempted tax benefits. PSUs have planned for about $7000 \mathrm{MW}$ installed solar in the next few years. Two of them in particular, namely NTPC and Coal India Limited (CIL), have agreed to invest for $3300 \mathrm{MW}$ and $750 \mathrm{MW}$ solar electricity respectively [59]. They are privileged to have modern management system (which enables them to include renewables in their business portfolio) and access to the energy market (which provides payment security).

Though transition towards privatisation has largely influenced the current state of on-grid solar on generation side, the transmission and distribution have remained mostly untouched. Transmission and distribution are not attractive for the involvement of private sector

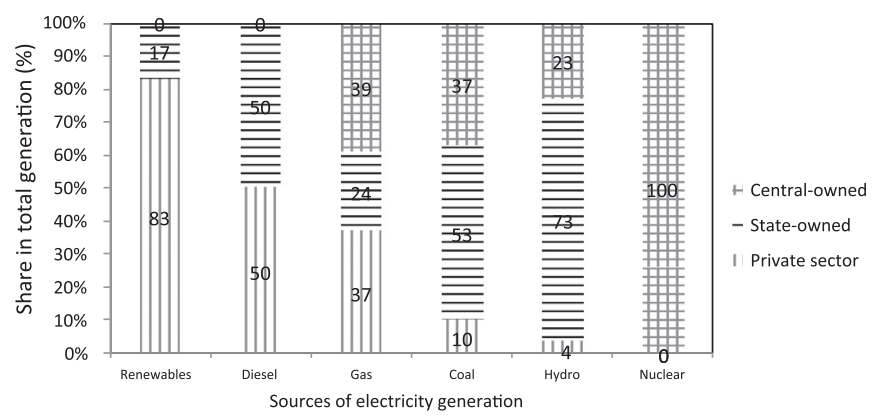

Fig. 3. The current share of electricity generation ownership in Indian energy market [4]. and are left as a responsibility of the State and Central Governments. This is because they require substantial investment in capital which is shared with public infrastructures. The income from transmission and distribution is also highly uncertain due to the theft of power, about $30 \%$ transmission and distribution losses and cross-subsidisation (which provides almost free electricity to farmers in Andhra Pradesh and Punjab and cheap electricity in other states and territories).

In addition to market privatisation, the broader historical transition of electricity sector towards renewable sources along with the new societal needs gave a momentum to the development of on-grid solar. Before 1990s, the major concern of the electricity sector was to address the widespread energy poverty across the country in the most affordable way. The development of hydroelectric and coal in the early years after independence was a response to this need. However, the gradual emergence of new societal needs including energy security, energy convenience and emissions reduction shifted the competition between different sources of electricity generation and ended up supporting ongrid solar development in the past 4 years. As soon as a consensus on energy security was formed in electricity sector in 1990s, the importance of renewables as a valuable substitute was realised. The emergence of energy equity and convenience in the late 1990s also pushed the growth of renewables towards on-grid renewable option such as wind power and small hydro. While on-grid solar benefited from this positive atmosphere, it could not get a significant share from this growth till late 2000s [4]. This has been mainly due to the high cost of solar technology compared to its conventional (such as coal) and renewable (such as wind) competitors. However, after 2008 and by the emergence of emissions reduction as a new societal need, the Central and State Governments targeted on-grid solar as a zero carbon energy solution and made long-term support for that [50]. This paved the way for investing on solar and opened a window of opportunity for that in India's established energy regime.

\subsection{The prospect of on-grid solar electricity}

While looking into historical transitions is necessary to understand the current development of solar electricity, considering the current state of the electricity sector and its uncertain driving forces in future is also insightful. This can answer the second question raised in Section 1: how will the future look for on-grid solar electricity based on the prospect of its driving forces?

The first important driving force affecting solar electricity is the prospect of competitions among hydro, nuclear, fossil and renewable sources in the electricity sector:

- The major growth in hydro power goes back to the socialistic policies of Jawaharlal Nehru's Government (1947-64). Since that time, there has been no significant growth for hydroelectricity, and hydro has been experiencing a decreasing share in total electricity generation [3]. Therefore, in future it is not expected to see a significant role for large scale hydro power in competition with different electricity sources in India.

- Nuclear energy was also standing in the similar situation till recently. The development of nuclear power had been limited since 1970s due to the country's nuclear test and the concern regarding military exploitation as well as the lack of domestic uranium reserves. The 2011 Fukushima's nuclear disaster in Japan also damaged public opinion. However, it is expected that nuclear power will rise again as a competitor to renewables in the near future. India envisages increasing the share of nuclear power to $9 \%$ of total electricity generation by 2020 . In a recent initiative, the State of Tamil Nadu inaugurated Kudankulam Nuclear Power Plant in 2013. The government has recently made some agreements to move towards this target, most importantly the U.S.-India Civil Nuclear Agreement for fuel and technology trade [60] and the AustraliaIndia Civil Nuclear Agreement for importing uranium from 
Australia [61]. Such international cooperation can facilitate the development of nuclear power in the future and make it a costcompetitive alternative to conventional sources, in terms of the levelised cost of electricity.

- The falling oil price is another disruptive force for the future of solar power. The downturn in global price of oil and gas since mid-2014 has motivated investors and large energy companies to continue power generation with fossil fuels. Indian energy sector can be influenced also by the recent the Iran Nuclear Deal. The lift of international sanctions and Iran's oil exports to India, as one of the major customers of Iran's oil [62], can create an unfavourable atmosphere for renewable sector. While the government feed-in tariff and carbon taxes can alleviate the current unfavourable situation for generation with renewables, they may adversely affect the global investment on renewable technologies as well. The falling oil price can slow down the R\&D in solar technologies and would impede the falling price of solar PVs in the next coming years.

- The last disruptive force expected to influence the future of solar is the huge reserves of coal (294 billion tonnes) in India. The problems with India's coal are the long-distant transportation (due to the concentration of coal on the eastern part of the country) and the poor quality of typical coal in India which cause environmental degradation. However, India needs about $445 \mathrm{GW}$ additional installed capacity by 2034 [63]. Looking practically, renewables are not able to solely meet this huge demand. It can be expected that coal will remain the preferred option in electricity generation in long-term future due to the sunk investment and its abundant and low cost resources in the country.

The second important driving force is the continuity of political support for renewables. The major hindrance to electricity sector's transition is the lack of sufficient and consistent social and political support, rather than purely technical issues. The Central Government is determined in shaping this consistency for the future of renewable electricity sector, especially for solar sector via different national and international initiatives. Some evidences for continuity of political supports are discussed as follows:

- In the first step, the Central Government hosted the biggest event for renewable investors at the Re-Invest Summit in New Delhi in February 2015. Though the meeting was about the future of all renewable sources, it mainly aimed to mobilise resources for the future of the solar sector. The Re-Invest Summit can be seen as a turning point for solar since it linked manufacturers, developers and investors, and also brought together different Ministries (stakeholders) engaged in the development of renewables. The government is also running another campaign, called 'Make in India' to encourage the domestic manufacturing of technologies, including wind turbines and solar PVs. This type of national campaign is shaping a supporting social and political environment for the solar sector, bringing consensus between stakeholders and attracting local and international investors to the sector in the future.

- The Government of India has significantly raised the target for solar electricity to $100 \mathrm{GW}$ by 2022. This is, what has been referred to as, the change of mind-set "from thinking in MW to thinking in GW"6 when it comes to solar electricity. The government needs to maintain the continuity of its previous supports and also to start new initiatives. With this respect, the government has announced Power Purchase Agreement and Viability Gap Funding as two important policy tools for realising the on-grid solar electricity targets. The government has requested the Ministry of Power to increase the RPO for solar to $10.5 \%$ in order to ensure attaining the

\footnotetext{
${ }^{6}$ Quoted from PM Modi in the inauguration of the Re-Invest Summit, $15^{\text {th }}$ of February 2015, New Delhi.
}

100 GW goal by 2022. The MNRE also has announced the installation of four Ultra Mega Solar Power Plants (UMSPPs) as well as 25 projects, each of $500 \mathrm{MW}$, by 2020 [59].

- The US President's visit to India in 2015 with a joint commitment for emissions reduction can be seen as another landmark for solar electricity. It shapes a more favourable political support for the future of renewables and solar in particular. Both countries agreed on the partnership to advance clean energy research which includes funding for research in three main areas including solar energy. The US Trade and Development Agency (USTDA) and the US Overseas Private Investment Corporation (USOPIC) agreed to provide loans for the Indian clean energy projects. The Export-Import Bank of US was also committed to financing clean energy projects with IREDA [59].

- The Indian government's pledge in the 2015 Conference of Parties (COP21) in Paris and then its ratification in 2016 can form a clear international commitment and also a political determination for a low carbon future in India. The consensus made in COP21 has made parties to transform energy sector and to move towards renewable sources through nationally-determined low carbon pathways. In this case, no matter how much cheap coal reserves a country such as India has and whether it is economical to generate renewable electricity or not, emissions reduction is a binding commitment. This commitment can shape a virtuous cycle and give further momentum to the development of the Indian renewables sector.

\subsection{Challenges ahead for on-grid solar sector}

While there has been great effort in promoting solar electricity, some major concerns still persist, which need to be addressed. The first is the necessity of boosting solar energy manufacturing units. India is currently capable of manufacturing the module segment of solar PV but is still dependent on foreign technologies in silicon, wafer and cell segments. The JNNSM has introduced policies for supporting manufacturing sector by imposing restrictions on the import of crystalline silicon technology. However, this policy has been criticised as it has failed to achieve domestic manufacturing, and instead, has pushed developers towards the import of cheap thin film modules (alternatives to silicon) from the US and China [14]. Import substitution and proactive localisation of renewable energy technologies have been suggested as directional industry strategies to address these concerns based on the expereinces from developing countries [64].

The second is the necessity to deal with cross-subsidisation in order to make solar generated electricity more attractive for users. In many States, the current industrial and commercial tariffs are high enough to get solar power (bundle price in PPAs) to grid parity. It can be seen as an opportunity to justify solar electricity between users. However, the distribution companies may not be willing to feed solar power into the grid as they lose the high paying consumers (industrial and commercial) and just remain with agriculture and household users who pay much less according to the pre-defined tariff.

The last but not the least is the necessity to make some existing policies effective for the solar sector. RPOs and RECs are two important policies that should become more effective. Since most of distribution companies are State-owned, RPOs legislated by the Federal Government are not fully enforceable at State level [14]. The MNRE and Ministry of Power also cannot take effective action without the support of the State Governments. What needs to be done is that SERCs specify obligatory RPO regulations and mandate distribution companies to comply with them. There are, however, some successful stories such as Chhattisgarh and Tamil Nadu Governments' enforcements that obliged entities to meet RPOs. Due to the lack of enforceable RPOs, there is no demand for RECs accordingly, especially when the floor price for REC is higher than the estimated cost of generation of solar electricity (according to [14]). An established market for REC trade with a reasonable price can address this issue. In order to assess 
the effectiveness of policies, a modelling approach called 'transitions modelling', has been introduced in the literature [65]. The implementation of this approach in India's electricity sector can be a future potential investigation towards the quantitative assessment of solar policies $[66,67]$.

\section{Conclusions}

The recent growth in on-grid solar electricity cannot be fully understood unless by analysing the historical transitions in electricity generation that have laid the ground for this growth. In order to explain the resurgence of solar PV electricity in India, this paper reviewed the transitions in governmental intervention's approach and in the primary energy source of electricity generation. On the one hand, the gradual emergence of societal needs in electricity sector from satisfying energy demand with conventional sources to reducing emissions with gridconnected renewables has legitimised the development of on-grid solar electricity generation. On the other hand, moving towards partially liberalised electricity market has allowed private sector to invest in solar electricity generation and to assist the government in removing the investment barriers.

While historical transitions explain the ongoing rise of solar power in India, looking into the future is still required to envision the prospective dynamics and to secure its continuous growth in the future. The second objective of the study was achieved by envisioning the situation of solar electricity sector with respect to two major driving forces. The first one was the prospect of competition among hydro, nuclear, fossil fuels and renewable sources. It was concluded that while renewables are expected to grow exponentially, the future of electricity generation in India (at least till 2022) can be still dominated by coal, and any plan and target for the electricity sector should take that into account. The second driving force examined in this paper was the political support for renewables and their continuation in the future. It is likely that solar electricity can rapidly grow under current conditions as the government has appeared supportive of renewables. Arranging international meetings for attracting foreign investments to the sector, increasing the targets for on-grid solar to $100 \mathrm{GW}$ and engaging in international partnerships addressing climate change issues are the evidences of this supportive political environment.

\section{Acknowledgement}

Enayat A. Moallemi thanks the University of Melbourne for providing Australian Federal Government scholarships, International Postgraduate Research Scholarship (IPRS) and Australian Postgraduate International Award (APA), for conducting this research. The authors thank four anonymous reviewers for their constructive comments on the earlier version of this paper. They would also like to thank the former Secretary of the Ministry of New and Renewable Energy in the Government of India, Mr. Rohit Kansal, for his comments on India's electricity sector.

\section{References}

[1] World Bank. World Development Indicators. World Bank. 〈https://www.google. com/publicdata/explore?Ds=d5bncppjof8f9 > 1960-2013

[2] GoI. Interim report of the expert group on low carbon strategies for inclusive growth. Planning Commission, Government of India; 2011

[3] CEA. Growth of electricity sector in India from 1947-2015. Central Electricity Authority, Ministry of Power, Government of India; 2015

[4] CEA. Growth of electricity sector in India from 1947-2013. Central Electricity Authority, Ministry of Power, Government of India; 2014

[5] MoP. Growth of electricity sector in India from 1947-2011. Government of India, Ministry of Power; 2011.

[6] MoP. Monthly All India Installed Generation Capacity Report. Ministry of Power; 2014

[7] Meenawat H, Srivastava N. Planning for the Future: decision making on Energy Policy in India. In: Hezri AA, Hofmeister W, editors. Toward Green Economy: In Search of Sustainable Energy Policies for the Future. Konrad-Adenauer-Stiftung.
2012.

[8] Moallemi EA, Ahamdi A, Afrazeh A, Bagheri Moghaddam N. Understanding systemic analysis in the governance of sustainability transition in renewable energies: the case of fuel cell technology in Iran. Renew Sustain Energy Rev 2014;33:305-15.

[9] Moallemi EA, Ahmadi A, Afrazeh A, Bagheri Moghaddam N. Assessing the performance of transition towards renewable energy: case study of Iran's fuel cell technology. J Corp Citizsh 2015;58:137-58.

[10] McCrone A. Global trends in renewable energy investment 2015. Frankfurt School of Finance and Management Frankfurt; 2015

[11] IEA. World energy investment outlook. OECD/IEA. 2014

[12] GoI. Report of the working group on power for eleventh plan (2007-2012). Ministry of Power, Governemnt of India; 2007

[13] GoI. Report of the working group on power for twelfth plan (2012-2017). Ministry of Power, Governemnt of India; 2012

[14] Bhushan C, Goswami N, Kumarankandath A, Agrawal KK, Kumar J. State of renewable energy in India: a citizen's report: centre for science and environment; 2014.

[15] Sawhney A. Renewable energy policy in India: addressing energy poverty and climate mitigation. Review of Environmental Economics and Policy; 2013.

[16] MNRE. Physical Progress (Achievements): Cumulative deployment of various Renewable Energy Systems. Ministry of New \& Renewable Energy, Government of India: 〈http://www.mnre.gov.in/mission-and-vision-2/achievements/〉; 2016

[17] UNEP. Global trends in renewable energy investment UNEP Collaborating Centre for Climate and Sustainable Energy Finance, Bloomberg New Energy Finance, Frankfurt School of Finance and Managemen, United Nations Environment Programme; 2012

[18] INFORSE. International Network for Sustainable Energy. 〈http://www.inforse.org/ europe/dieret/Solar/solar.html ; 2015

[19] Sahu BK. Solar energy developments, policies and future prospectus in the state of Odisha, India. Renew Sustain Energy Rev 2016;61:526-36.

[20] Sahoo SK. Renewable and sustainable energy reviews solar photovoltaic energy progress in India: a review. Renew Sustain Energy Rev 2016;59:927-39.

[21] Srilakshmi G, Venkatesh V, Thirumalai NC, Suresh NS. Challenges and opportunities for Solar Tower technology in India. Renew Sustain Energy Rev 2015:45:698-709.

[22] Chandel SS, Shrivastva R, Sharma V, Ramasamy P. Overview of the initiatives in renewable energy sector under the national action plan on climate change in India. Renew Sustain Energy Rev 2016;54:866-73.

[23] IEA. World Energy Outlook 2014-Power Generation Investment Assumptions; 2014

[24] IEA. World Energy Outlook 2007: China and India Insights. International Energy Agency (IEA); 2007

[25] World Bank. Paving the way for a transformational future: lessons from Jawaharlal Nehru national solar mission phase I. World Bank - Energy Sector Management Assistance Program (ESMAP); 2013

[26] MoP. Ministry of power annual report. Minstry of Power, Government of India. 〈http://powermin.nic.in/annual-reports-year-wise〉; 2015

[27] GoI. Annual Report on the Working of State Electricity Boards \& Electricity Departments (1999-2014). Power \& energy division, planning commission, Government of India. 〈http://planningcommission.gov.in/reports/genrep/annrep. php?Repts=b annrep.htm); 2015

[28] GoI. National tariff policy. New Delhi: Ministry of Power, Governemnt of India. 〈http://powermin.nic.in/whats_new/pdf/Tariff_Policy.pdf); 2006

[29] MNRE. Jawaharlal Nehru National Solar Mission. Ministry of New and Renewable Energy, Government of India; 2010

[30] MoP. Electricity Act 2003. New Delhi: Ministry of Power, Government of India. 2003

[31] de Haan J, Rotmans J. Patterns in transitions: understanding complex chains of change. Technol Forecast Soc Change 2011;78:90-102.

[32] Geels F. Technological transitions as evolutionary reconfiguration processes: a multi-level perspective and a case-study. Res Policy 2002;31:1257-74.

[33] Moallemi E.A., George B., Aye L., Webb J. Towards an integrated conceptual framework for understanding transition dynamics. In: Proceedings of the 5th International Conference on Sustainability Transitions: Impact and Institutions, Utrecht; 27-29 August 2014.

[34] Moallemi EA, de Haan FJ, Webb JM, George BA, Aye L. Transition dynamics in state-stimulated niche empowerments: Experiences from Indian electricity sector. Technological Forecasting and Social Change. Available online 9 November 2016, ISSN 0040-1625, http://dx.doi.org/10.1016/j.techfore.2016.10.067.

[35] Hall PA. Varieties of capitalism: Wiley Online Library; 2001.

[36] Shrimali G, Rohra S. India's solar mission: a review. Renew Sustain Energy Rev 2012; 16:6317-32.

[37] Gulati M. Developing solar power lessons from India's national solar mission. WWF South Africa; 2012.

[38] Victor DG, Heller TC, Hope E. The political economy of power sector reform: the experiences of five major developing countries. Cambridge University Press; 2007.

[39] GoI. The Electricty Act 1948. Government of India. 〈http://cercind.gov.in/ ElectSupplyAct1948.pdf $; 1948$

[40] Bank W. India 1991 Country Economic Memorandum. Country Operations Division, India Country Department, Asia Region World Bank. 〈http://www-wds. worldbank.org/external/default/WDSContentServer/WDSP/IB/1991/08/23/ 000009265_3960930195417/Rendered/PDF/multi0page.pdf); 1991.

[41] Ghosh A. Pathways through financial crisis: India. Glob Gov 2006;12:413-29.

[42] Mukherjee M. Private participation in the Indian power sector: lessons from two decades of experience: World Bank Publications; 2014. 
[43] GoI, The Electricity Act (Amendments) 1948. Government of India, New Delhi. 〈http://parliamentofindia.nic.in/ls/bills/1991/1991-47.htm); 1991

[44] GoI. Annual Report on the Working of State Electricity Boards and Electricity Department. 〈http://planningcommission.gov.in/reports/genrep/seb/seb1999/ index.php?Repts=seb1999.htm $\rangle ; 1999$

[45] Bagheri Moghaddam N, Mousavi SM, Nasiri M, Moallemi EA, Yousefdehi H. Wind energy status of Iran: evaluating Iran's technological capability in manufacturing wind turbines. Renew Sustain Energy Rev 2011;15:4200-11.

[46] Sharma A, Srivastava J, Kar SK, Kumar A. Wind energy status in India: a short review. Renew Sustain Energy Rev 2012;16:1157-64.

[47] Kar SK, Sharma A. Wind power developments in India. Renew Sustain Energy Rev 2015;48:264-75.

[48] GoI. Eleventh Five Year Plan (2007-2012). Planning Commission, Government of India. 〈http://planningcommission.nic.in/plans/planrel/11thf.htm〉; 2007

[49] GoI. Tenth Five Year Plan 2002-07. Planning Commission, Government of India. 〈http://planningcommission.nic.in/plans/planrel/fiveyr/10th/10defaultchap. htm $>2002$

[50] GoI. National Action Plan on Climate Change, Prime Minister's Council on Climate Change; 2008.

[51] Kapoor K, Pandey KK, Jain AK, Nandan A. Evolution of solar energy in India: a review. Renew Sustain Energy Rev 2014;40:475-87.

[52] Sharma NK, Tiwari PK, Sood YR. Solar energy in India: strategies, policies, perspectives and future potential. Renew Sustain Energy Rev 2012;16:933-41.

[53] MNRE. State wise estimated solar power potential in the country. Ministry of New \& Renewable Energy, Government of India. 〈http://mnre.gov.in/file-manager/ UserFiles/Statewise-Solar-Potential-NISE.pdf); 2015

[54] GERC. Gujarat State Solar Power Policy. Gujarat Electricity Regulatory Commission (GERC). 〈http://geda.gujarat.gov.in/policy_files/Solar\%20Power \%20policy\%202009.pdf); 2009

[55] GoR. Rajasthan Solar Policy. Energy Department, Government of Rajasthan. 〈http://www.rrecl.com/PDF/Solar\%20Policy\%202014_08.10.2014.pdf); 2011

[56] Earth Policy Institute. Cumulative Installed Solar Photovoltaics Capacity in India, 2000-2013. 〈http://www.earth-policy.org/data_center/C23〉; 2015

[57] MNRE. Re-invest 2015 Report: Investors Guide. New Delhi, India: First Renewable Energy Global Investors Meet \& Expo, Ministry of New and Renewable Energy. http://2015.re-invest.in/Document/orginal/15.RE-Invest_2015_Investors_
Guide.pdf; 2015

[58] MNRE. Draft Scheme for Development of Solar Parks and Ultra Mega Solar Power Projects. New Delhi, India: Ministry of New and Renewable Energy. http://www. seci.gov.in/upload/uploadfiles/files/Draft-Scheme-Solar-Park-and-Ultra-MegaSolar-Power-Projects-for-comments.pdf; 2014

[59] MNRE. The First Re-Invest 2015 Conference Sessions' Report. New Delhi, India: Distributed in paper copy during the First Renewable Energy Global Investors Meet \& Expo (Re-Invest 2015), Ministry of New and Renewable Energy; 2015

[60] US-Gov. Fact Sheet: U.S.- India civil nuclear cooperation initiative - bilateral agreement on peaceful nuclear cooperation. 〈http://2001-2009.state.gov/r/pa/prs/ ps/2007/89552.htm); 2007

[61] GoI. National interest analysis: agreement between the Government of Australia and the Government of India on Cooperation in the Peaceful Uses of Nuclear Energy. Department of Atomic Energy, Government of India. 〈http://dae.nic.in/ writereaddata/aus_nca_0.pdf); 2014

[62] Verma N. India's Iran oil imports set to surge to seven-year high in 2016/17. Institution. 〈http://www.reuters.com/article/us-india-iran-oil-importsidUSKCN0 $\times 11 \mathrm{ZH}\rangle ; 2016$.

[63] PwC. Future of India: The Winning Leap-Breaking new ground by deploying solutions for rapid, sustainable and resource-efficient growth. PwC India. 〈http:// www.pwc.com/sg/en/publications/assets/future-of-india-the-winning-leap.pdf); 2014

[64] Bagheri Moghaddam N, Mousavi SM, Moallemi EA, Nasiri M. Formulating directional industry strategies for renewable energies in developing countries: the case study of Iran's wind turbine industry. Renew Energy 2012;39:299-306.

[65] Holtz G, Alkemade F, de Haan F, Köhler J, Trutnevyte E, Luthe T. et al. Prospects of modelling societal transitions: position paper of an emerging community. Environmental Innovation and Societal Transitions; 2015.

[66] Moallemi EA, Haan FJ, George BA, Webb JM, Lu A. Dynamic modelling of energy transitions using a coupled modelling-narrative approach. In: Proceedings of the 21st International Congress on Modelling and Simulation (MODSIM2015); Gold Coast, Australia; November 29 - December 42015.

[67] Moallemi EA, Aye L, de Haan FJ, Webb JM. Policy analysis of renewable electricity development in India: From a transition modelling perspective. In Proceedings of the 34th International Conference of the System Dynamics Society: Black Swans and Black Lies, July 17 - July 21. Delft, The Netherlands, 2016. 


\section{University Library}

\section{- M M I N E R VA A gateway to Melbourne's research publications}

Minerva Access is the Institutional Repository of The University of Melbourne

Author/s:

Moallemi, EA;Aye, L;Webb, JM;de Haan, FJ;George, BA

Title:

India's on-grid solar power development: Historical transitions, present status and future driving forces

Date:

2017-03-01

Citation:

Moallemi, E. A., Aye, L., Webb, J. M., de Haan, F. J. \& George, B. A. (2017). India's on-grid solar power development: Historical transitions, present status and future driving forces. Renewable and Sustainable Energy Reviews, 69, pp.239-247. https://doi.org/10.1016/ j.rser.2016.11.032.

Persistent Link:

http://hdl.handle.net/11343/120663 